\title{
Methane emissions from Amazonian Rivers and their contribution to the global methane budget
}

\author{
Henrique O. Sawakuchi, David Bastviken, Andre O. Sawakuchi, Alex V. Krusche, Maria V. \\ R. Ballester and Jeffrey E. Richey
}

\section{Linköping University Post Print}

\section{Tweet}

N.B.: When citing this work, cite the original article.

Original Publication:

Henrique O. Sawakuchi, David Bastviken, Andre O. Sawakuchi, Alex V. Krusche, Maria V. R. Ballester and Jeffrey E. Richey, Methane emissions from Amazonian Rivers and their contribution to the global methane budget, 2014, Global Change Biology, (20), 9, 2829-2840. http://dx.doi.org/10.1111/gcb.12646

Copyright: Wiley. http://eu.wiley.com/WileyCDA/

Postprint available at: Linköping University Electronic Press http://urn.kb.se/resolve?urn=urn:nbn:se:liu:diva-110267 
Title: Methane emissions from Amazonian Rivers and their contribution to the global methane budget

Running head: Methane emissions from Amazonian Rivers

Henrique O. Sawakuchi ${ }^{1 *}$, David Bastviken ${ }^{2}$, André O. Sawakuchi $^{3}$, Alex V. Krusche ${ }^{1}$, Maria Victoria R. Ballester ${ }^{1}$, Jeffrey E. Richey ${ }^{4}$

${ }^{1}$ Environmental Analysis and Geoprocessing Laboratory, Center for Nuclear Energy in Agriculture, University of São Paulo, Av. Centenário, 303, Piracicaba, SP 13400-970, Brazil; ${ }^{2}$ Department of Thematic Studies - Water and Environmental Studies, Linköping University, Linköping, SE-581 83, Sweden; ${ }^{3}$ Departament of Sedimentary and Environmental Geology, Institute of Geosciences, University of São Paulo, Rua do Lago, 562, São Paulo, SP 05508-080, Brazil $;{ }^{4}$ School of Oceanography, University of Washington, Seattle, WA 98195-7940, USA.

*Corresponding author: Henrique O. Sawakuchi

Phone: +55 19 34294076; Fax: +55 1934294059

e-mail: henrique.sawakuchi@usp.br

Keywords: methane flux, $\mathrm{CH}_{4}$, ebullition, tropical rivers, Amazon, greenhouse gas, natural emission.

Type of paper: Primary Research Articles 


\begin{abstract}
Methane $\left(\mathrm{CH}_{4}\right)$ fluxes from world rivers are still poorly constrained, with measurements restricted mainly to temperate climates. Additional river flux measurements, including spatio-temporal studies, are important to refine extrapolations. Here we assess the spatiotemporal variability of $\mathrm{CH}_{4}$ fluxes from the Amazon and its main tributaries, the Negro, Solimões, Madeira, Tapajós, Xingu, and Pará Rivers, based on direct measurements using floating chambers. Sixteen out of 34 sites were measured during low and high water seasons. Significant differences were observed within sites in the same river and among different rivers, types of rivers, and seasons. Ebullition contributed to more than $50 \%$ of total emissions for some rivers. Considering only river channels, our data indicate that large rivers in the Amazon Basin release between 0.40 and $0.58 \mathrm{Tg} \mathrm{CH}_{4} \mathrm{yr}^{-1}$. Thus, our estimates of $\mathrm{CH}_{4}$ flux from all tropical rivers and rivers globally were, respectively, $19-51 \%$ to 31 $84 \%$ higher than previous estimates, with large rivers of the Amazon accounting for 22$28 \%$ of global river $\mathrm{CH}_{4}$ emissions.
\end{abstract}




\section{Introduction}

Despite their small areal extent inland waters play an important role in regional and global carbon balances as sources of both $\mathrm{CO}_{2}$ (Battin et al., 2009, Cole et al., 2007, Richey et al., 2002, Tranvik et al., 2009) and $\mathrm{CH}_{4}$ (Bastviken et al., 2011). Recent estimates show that inland waters outgas around 2.1 $\mathrm{Pg} \mathrm{C} \mathrm{yr}^{-1}$ as $\mathrm{CO}_{2}$ (Raymond et al., 2013) and 0.65 $\mathrm{Pg} \mathrm{C} \mathrm{yr}^{-1}$ as $\mathrm{CH}_{4}$ (Bastviken et al., 2011).

Global estimates of $\mathrm{CH}_{4}$ release from rivers are on the order of $1.5 \mathrm{Tg} \mathrm{CH}_{4} \mathrm{yr}^{-1}$ (Bastviken et al., 2011). However, due to the scarcity of river $\mathrm{CH}_{4}$ data this estimate was based on a small number of studies, largely from temperate areas. The lack of data from tropical rivers is particularly important given their large area and higher rate of emissions per unit area compared to temperate ecosystems (Bastviken et al., 2011).

Most of the previous $\mathrm{CH}_{4}$ flux measurements in the Amazon were done in the adjacent areas of the river channel, such as the floodplains locally called "varzeas", lakes and flooded forest (Bartlett et al., 1988, Belger et al., 2011, Crill et al., 1988, Devol et al., 1988, Devol et al., 1990, Rosenqvist et al., 2002) or in hydroelectric (Abril et al., 2005, Kemenes et al., 2007, Lima, 2005).

However, the large concentration of $\mathrm{CH}_{4}$ found in the Amazon river channel (Richey et al., 1988) have shown the potential importance of this river itself as a source of $\mathrm{CH}_{4}$ to the atmosphere. Significant $\mathrm{CH}_{4}$ fluxes from three other tropical rivers were recently estimated in Africa (Kone et al., 2010). However, these studies focused only on the diffusive component of $\mathrm{CH}_{4}$ fluxes, calculated from water-air $\mathrm{CH}_{4}$ concentration gradient and piston velocity, whereas recent studies have shown that ebullition can also be important 
in running waters (Baulch et al., 2011). Therefore, studies on $\mathrm{CH}_{4}$ emissions demand the evaluation of both ebullition and diffusive components.

Here we present the results from total flux measurements separated into diffusive and ebullitive components in the Amazon River and most of its main tributaries (Solimões, Negro, Madeira, Tapajós and Xingu Rivers), as well as their general spatial and temporal distribution. Our data points to a more significant role of the Amazon basin in the global $\mathrm{CH}_{4}$ budget than previously estimated. 


\section{Methods}

Sites description and sampling scheme

The Amazon river basin stands out as the largest river system on Earth (Archer, 2005), formed by an extensive network of tributaries draining approximately 6 million $\mathrm{km}^{2}$ of Andean and lowland basins that feed the $6,700 \mathrm{~km}$ long main river channel (Richey et $a l ., 1988)$. In general, the weather is characterized by high temperatures with low variations throughout the year and is divided into well defined wet and dry seasons. Precipitation has strong seasonality modulated by shifts in the Intertropical Convergence Zone (ITCZ). The southward shift of the ITCZ during austral summer brings a large amounts of moisture to the basin, generating a monsoon precipitation system (Grimm et al., 2005, Vera et al., 2006), which results in large variations in river water levels.

The Amazon river tributaries have distinct characteristics related to their water types and channel morphology. A general classification by water color is frequently used to separate rivers in the Amazon Basin (Sioli, 1985). Black water rivers such as Negro River usually drain lowland areas with heavily weathered rocks and sandy soils and have high dissolved organic matter content, low amounts of suspended sediments, median turbidity, low ionic strength, and high acidity (Mayorga \& Aufdenkampe, 2002, Sioli, 1985). White water rivers such as Solimões and Madeira Rivers have their upstream catchment draining Andean areas and have high suspended sediment loads and dissolved solids concentrations, with neutral to alkaline pH (Mayorga \& Aufdenkampe, 2002, Sioli, 1985). Clear water rivers such as Tapajós and Xingu drain the Brazilian shield and have low suspended 
sediment loads, intermediary ionic content and slightly alkaline pH (Mayorga \& Aufdenkampe, 2002, Sioli, 1985).

Amazonian rivers have different types of depositional systems with varied sedimentary dynamics and sediment distribution (Archer, 2005, Latrubesse et al., 2005). This heterogeneity in sedimentary dynamics is seen in the occurrence of channel areas with higher deposition of organic rich sediment where $\mathrm{CH}_{4}$ production is favored. Great differences in channel morphology and sediment deposition occur downstream from our studied site in some tributaries, as observed during field trips for $\mathrm{CH}_{4}$ measurements. The mouths of the Negro, Xingu and Tapajós Rivers are blocked by sediment bars from the Amazon main channel. This damming of the lower portion of these tributaries generates wide channels (up to $19 \mathrm{~km}$ wide) with low water flow and regular wave action, promoting lake-like sedimentary dynamics in which deposition of organic rich mud in the central portion of the channel is common. Rivers draining highlands in the Andes such as the Solimões and Madeira have high suspended sediment load and their lowermost reaches are characterized by relatively narrow (1.5-3.5 km wide) and straight channels dominated by sand deposition with mud deposition occurring mainly over adjacent floodplains. The Amazon main channel has these same characteristics upstream from the Xingu River mouth. The Xingu River has an unique channel morphology. Its upstream sectors drain bedrock from an incised valley and have relatively low sediment deposition rates due to high water flow. This is in contrast with its depositional lake-like river mouth.

Concentrations and fluxes (total flux, diffusive flux, and ebullition) of $\mathrm{CH}_{4}$ to the atmosphere were measured on 52 occasions at 34 sites at the Negro, Solimões, Preto da Eva, Madeira, Tapajós, Xingu, Pará and Amazon Rivers and at a white water lake (Lake Curuai) in the Amazon River floodplain. Sixteen of these sites were measured during both 
high (May 2012) and low (November 2012) water seasons and one site at Tapajós River was also measured in the falling water season (July 2012) (site number 14 in Figure 1). The remaining sites were visited only once during low, high or falling water season (see Table 1

for details). Sites in the Amazon River, near Óbidos, (numbered 27, 28 and 29 in Figure 1 and Table 1) and sites in the Pará River near Belém (numbered 23, 24 and 25) represents two cross-section profiles where measurements were made at three locations equally spaced across the channel of those rivers. Figure 1 and Table 1 show details about sampling periods and additional information about the sites.

\section{$\mathrm{CH}_{4}$ flux measurements}

Surface water samples were collected simultaneously with flux measurements. $\mathrm{CH}_{4}$ concentrations in water were determined after headspace extraction according to the methods of Bastviken et al. (2010). Dissolved $\mathrm{CH}_{4}$ concentration was calculated using Henry's Law adjusted for temperature according to Wiesenburg and Guinasso (1979) following analysis in a Shimadzu GC17A gas chromatograph, modified to contain an online methanizer coupled to a FID detector.

Chamber deployments for $\mathrm{CH}_{4}$ total flux at all sites were performed in the center of the river channels using floating chambers as described by Bastviken et al. (2010). Measurements were made for approximately one hour at each site while drifting, using 7 to 15 chambers separated $1.5 \mathrm{~m}$ from each other. The chambers used were of the same type as previously tested and shown to produce non-biased flux values relative to other flux measurement methods (Cole et al., 2010, Galfalk et al., 2013). Using many chambers simultaneously increases the probability of capturing ebullition and allows for the 
calculation of diffusive flux and ebullition. Total flux and the contribution from diffusive and ebullitive emissions were calculated according to Bastviken et al. (2004, 2010). Samples from chambers were withdrawn using syringes and immediately transferred to 20 $\mathrm{ml}$ glass vials filled with salt solution to prevent solubility and capped with a $10 \mathrm{~mm}$ thick butyl rubber stopper and an aluminum crimp seal. Gas concentrations were measured by gas chromatography as above. Air temperature, atmospheric pressure and wind speed were measured with a weather station (HOBO; Onset Computer Corporation, Bourne, MA, USA) installed on the boat and water temperature was measured with a $\mathrm{pH}$ meter (Orion 290APlus; Thermo Fisher Scientific Inc., Waltham, MA, USA). Flux measurements were done with wind speed ranging from 0.36 to $6 \mathrm{~m} / \mathrm{s}$.

\section{Diffusive flux calculations}

Diffusive flux across the water surface into the floating chamber can be described by the equation:

$F=k \cdot\left(C_{w}-C_{f c}\right)$

where $F$ is flux $\left(\mathrm{mol} \mathrm{m} \mathrm{m}^{-2}\right), k$ the piston velocity $\left(\mathrm{m} \mathrm{d}^{-1}\right), \mathrm{C}_{w}$ is the concentration of $\mathrm{CH}_{4}$ measured in the water $\left(\mathrm{mol} \mathrm{m}^{-3}\right)$, and $\mathrm{C}_{f c}$ is the $\mathrm{CH}_{4}$ concentration in the water at equilibrium with the $\mathrm{CH}_{4}$ partial pressure in the floating chamber (Cole \& Caraco, 1998). However, in equation (1) the flux is partially driven by the change in concentration, which will decrease with time in the chambers as the internal concentration increase. Therefore, this simple calculation will underestimate the instantaneous flux rate. In order to reduce this error, we solved for $k$ to estimate instantaneous flux (e.g. the flux for each time step; here time zero (0) to time "t", $F_{0-t .}$. First, $F$ is expressed as 
$F_{0-t}=\frac{\left(n_{t}-n_{0}\right)}{A}$

where $n_{0}$ and $n_{t}$ are the number of moles in the chamber at time zero and time " $t$ " and $A$ is the chamber area. Then, the moles are expressed as $P_{0}$ and $P t$ given conversion according to the common gas law $(P V=n R T)$. Finally, the concentration numbers are also expressed as corresponding gas pressure following Henrys Law $\left(C=K_{h} P\right)$. Hence, by making this equation continuous, instead of having discrete time steps (e.g. $d P / d t$ instead of $P_{t}-P_{0}$ ), Equation (1) could be rewritten as:

$\left(\frac{d P}{d t}\right) \cdot\left(\frac{V}{R \cdot T \cdot A}\right)=k \cdot\left(K_{h} \cdot P_{w}-K_{h} \cdot P_{0}\right)$

where $d P / d t$ is the slope of $\mathrm{CH}_{4}$ accumulation in the chamber $\left(\mathrm{Pa} \mathrm{d}^{-1}\right), V$ is the chamber volume $\left(\mathrm{m}^{3}\right), R$ is the gas constant $\left(8.314 \mathrm{~m}^{3} \mathrm{~Pa} \mathrm{~K}^{-1} \mathrm{~mol}^{-1}\right), T$ is temperature $(\mathrm{K}), P_{w}$ is the partial pressure of $\mathrm{CH}_{4}$ in the chamber at equilibrium with $C_{w}(\mathrm{~Pa}), P_{0}$ is the partial pressure of $\mathrm{CH}_{4}$ in the chamber at time 0 (approximately the same than atmosphere), and $K_{h}$ is the Henry's Law constant for $\mathrm{CH}_{4}\left(\mathrm{~mol} \mathrm{~m}^{-3} \mathrm{~Pa}^{-1}\right)$. Thus,

$k=\left(\frac{d P}{d t}\right) \cdot \frac{V \cdot\left(P_{w}-P_{0}\right)}{K_{h} \cdot R \cdot T \cdot A}$

After solving for $k$ using equations 4 the instantaneous flux was calculated using equation (1). The temperature dependence of $K_{h}$ was calculated from the Bunsen coefficients given by Wiesenburg and Guinasso (1979).

\section{Ebullition calculations}

To determine which chambers captured ebullition we used the distributions and variance of the apparent piston velocities as described in Bastviken et al. (2004, 2010). First the calculated (apparent) $k$ values for each chamber were transformed into $k_{600}$ values, 
allowing $k$ values to be compared for any gas and temperature (Jahne et al., 1987, Wanninkhof, 1992). Ebullition makes calculated apparent $k_{600}$ values substantially higher than those receiving $\mathrm{CH}_{4}$ only by diffusive flux, allowing the separation of the two flux components. In each measurement, the apparent $k_{600}$ of each chamber was divided by the minimum $k_{600}$ found in the same set of chambers, which we attributed solely to diffusive flux. Moreover, in a given area and time, the diffusive flux has a constant rate. Thus, chambers receiving only diffusive flux would have similar and lower flux rates and could be distinguished from the chambers receiving ebullition. However, in one site all chambers displayed a large discrepancy in flux rates, indicating that all chambers could have received ebullition. In this case, as the lowest value was similar with the diffusion measured in nearby sites, we considered that value as diffusion. The frequency distribution of this ratio $\left(k_{600} /\right.$ minimun $k_{600}$ ) for all chambers clearly indicated two distinct groups of ratios, one between $0.99-2.0$ and another $>2$ (Figure 2). For this reason a ratio of 2 was chosen as threshold for significant inputs of $\mathrm{CH}_{4}$ into the chamber by ebullition. For the chambers that received ebullition flux we first calculated the diffusive flux from equation (1) using the site averaged $k_{600}$ from the other chambers which received diffusive flux only, with the remaining $\mathrm{CH}_{4}$ flux into the chambers attributed to ebullition only. For comparison among rivers, ebullition was normalized to the area covered by all chambers, including the chambers that did not receive ebullition, which were computed as 0 for average calculations.

\section{Classification of Sediment}


Most of the sites were surveyed for sediment type using a Van Veen grab sampler. Sediment types were divided into four general groups: mud, sand, a mixture of fine sand with mud and non-identified. The non-identified groups consisted of sites where we were not able to sample due to depth or malfunctioning of the grab sampler. However, water flow regime at these sites was similar to areas with sand or sand-mud sediments. Water depth was measured using a sonar (Garmin GPSMAP 521s; Garmin Ltd, Olathe, KS, USA).

Spatiotemporal statistical analysis

To understand the spatial and temporal $\mathrm{CH}_{4}$ flux variability we performed a series of comparisons including: (1) difference in $\mathrm{CH}_{4}$ fluxes within the same river; (2) differences in $\mathrm{CH}_{4}$ fluxes between rivers; (3) differences in $\mathrm{CH}_{4}$ fluxes for areas with different sediment types; (4) differences in $\mathrm{CH}_{4}$ fluxes between water types and (5) seasonal variations in $\mathrm{CH}_{4}$ fluxes. To obtain a more robust analysis in the seasonal comparison we used only data from sites that were measured in both low and high water seasons. Analysis of variance (ANOVA) followed by Tukey post-hoc tests with log transformed data were used to check for differences between comparisons. A nonparametric statistic was necessary for ebullition due to the non-normal distribution, even after log transformations. For that purpose we choose Kruskal-Wallis to test the influence of sediment type and depth on ebullition. All statistics were done using each chamber and deployment period as one independent measurement.

\section{Upscaling}


The surface area covered by rivers in the Amazon basin was obtained from the water class of the South America land cover map (Brown et al., 2003). In this map only rivers wider than $200 \mathrm{~m}$ were mapped, and since our measurements were done only in rivers wider than $1 \mathrm{~km}$ we decided not to consider rivers smaller than $200 \mathrm{~m}$ in our extrapolation. Further measurements in smaller rivers and streams are still needed to better constrain $\mathrm{CH}_{4}$ flux from riverine systems in the Amazon. Lakes in the floodplain of the Amazon River were removed while large depositional areas (lake-like) within channels included.

For a more precise upscaling of $\mathrm{CH}_{4}$ flux from rivers of the Amazon basin, we calculated each river flux rate separately and summed them to obtain whole basin estimates. For those rivers where different $\mathrm{CH}_{4}$ fluxes were identified in lake-like areas and straight fluvial channels, mean flux rates for these reaches were calculated separately. Seasonal average $\mathrm{CH}_{4}$ fluxes for low and high water seasons (each corresponding to a time period of six months) were calculated separately and then summed to compose the annual $\mathrm{CH}_{4}$ flux rate. The extrapolation to other large rivers in the Amazon basin that were not measured was done using the average from all rivers. Flux ranges for each river were calculated based on the average of the standard errors of the means. 


\section{Results}

An overview of the results is presented in Table 2. Dissolved $\mathrm{CH}_{4}$ concentrations ranged from 0.02 to $0.5 \mu \mathrm{M}$, with average total fluxes of 0.01 to $40.3 \mathrm{mmol} \mathrm{CH}_{4} \mathrm{~m}^{-2} \mathrm{~d}^{-1}$ and an overall average, excluding Curuai Lake, of $1.4 \mathrm{mmol} \mathrm{CH}_{4} \mathrm{~m}^{-2} \mathrm{~d}^{-1}$. Diffusive fluxes accounted for $66 \%$ of total emissions, with a range of single measurements from 0.01 to $18.6 \mathrm{mmol} \mathrm{CH}_{4} \mathrm{~m}^{-2} \mathrm{~d}^{-1}$, while the remaining $34 \%$ attributed to ebullition ranged from 0.2 to $35.7 \mathrm{mmol} \mathrm{CH}_{4} \mathrm{~m}^{-2} \mathrm{~d}^{-1}$ (Table 2). Ebullition was captured by at least one of the chambers in $36 \%$ of the measurements and when registered, its contributions varied from 5 to $83 \%$ of the total flux in a single measurement.

\section{Flux variability within rivers}

To test for spatial variability in $\mathrm{CH}_{4}$ flux within rivers we analyzed the longitudinal and cross-channel differences among sites within the same river. The cross-channel profiles were done in two locations, one in the Amazon and another in the Pará River. Due to limited replication for each specific site within each river for this comparison we used only the diffusive flux component. Ebullition is discussed in other comparisons below. A Oneway ANOVA followed by a Tukey post-hoc test $(\mathrm{p}<0.05)$ showed that at the river scale, diffusive fluxes were different in both longitudinal and cross-channel comparisons in all rivers. Fluxes in the Negro, Solimões and Madeira Rivers increased downstream. If we exclude estuarine sites in the Amazon River the same downstream increase was observed. The Tapajós River had an opposite pattern and the Xingu River had no clear spatial pattern (Figure 3). The cross-channel trends varied between the two rivers considered with higher 
fluxes in the center of the Amazon but an increasing trend from north to south banks of the Pará River (Figure 4).

River bed sediments influence on total flux

The influence of riverbed sediment type on total $\mathrm{CH}_{4}$ flux was tested by comparing emissions from locations with varying sediment type. The two end members are represented by sand substrate from channels with high water flow and mud substrate from wide channels with low water flow and deposition of suspended sediments. A mixed sandmud substrate was also considered. Using log transformed data, we observed significant differences in total flux comparing sites with different types of sediment (ANOVA, p-value $<0.001$ ) (Figure 5A). Significantly higher total fluxes were observed in sites with mud in riverbed sediments (Table 3). Average fluxes for non-identified, sand/mud mixture, and sand sediments were all lower and similar in magnitude (Table 3).

Flux variability among rivers and water type

We observed a wide range of total $\mathrm{CH}_{4}$ fluxes among rivers with averages ranging from $0.04 \mathrm{mmol} \mathrm{m}^{-2} \mathrm{~d}^{-1}$ in Madeira River to $6.0 \mathrm{mmol} \mathrm{m}^{-2} \mathrm{~d}^{-1}$ in Xingu River (more details in Table 2). Significant differences among rivers were tested using ANOVA test ( $p$-value < 0.001), followed by Tukey post-hoc (Figure 5B). The Xingu River had the highest total flux and was different from all other rivers. Average Xingu River emissions per $\mathrm{m}^{2}$ were 2-100 fold larger than corresponding emissions from the other rivers (Table 2). Tapajós and Amazon Rivers presented the second and third highest $\mathrm{CH}_{4}$ emissions, with an average total 
flux of 2.4 and $1.3 \mathrm{mmol} \mathrm{m}^{-2} \mathrm{~d}^{-1}$, respectively. These three highest river fluxes were all similar to, or higher than, our flux measurements at Lake Curuai (mean $=1.1 \mathrm{mmol} \mathrm{m}^{-2} \mathrm{~d}^{-}$

${ }^{1}$ ). The Madeira River had the lowest flux among all measured rivers (Table 2).

Clear water rivers had significantly higher total fluxes (mean $=4.6 \mathrm{mmol} \mathrm{m} \mathrm{m}^{-1}$ ), while white and black water rivers were statistically similar, with mean fluxes of 0.7 and $0.4 \mathrm{mmol} \mathrm{m} \mathrm{d}^{-2}$, respectively (ANOVA, $p<0.001$; Figure 5C, Table 3).

\section{Seasonal variability}

Since most of the sites measured during the falling water season were visited only on one occasion, they were not considered for this test. Here we choose only data from the 16 sites that were measured during low and high water seasons (Figure 1, Table 1). An overall analysis comparing all measurements done in low and high water seasons shows significantly higher emissions during low water (4.1 versus $0.9 \mathrm{mmol} \mathrm{m} \mathrm{d}^{-2}$; ANOVA, $p<$ 0.001; Figure 5D, Table 3). Considering seasonal variability for each river separately, all rivers had higher median fluxes during low water (Figure 6). However, statistically significant seasonal differences were only observed for Tapajós and Xingu Rivers (twoway ANOVA, $p$-value $=0,025)$.

\section{Ebullition}

In most rivers diffusion was the main component of $\mathrm{CH}_{4}$ emission. However, our results show that more than $50 \%$ of the total $\mathrm{CH}_{4}$ released by the Xingu River to the 
atmosphere can be attributed to ebullition. Ebullition was also registered in the Amazon, Tapajós, Negro, Pará and Solimões Rivers, but in lower proportions (Figure 7, Table 2).

The highest rates of ebullition were measured in sites with mud substrate between 10 and $20 \mathrm{~m}$ water depth (Figure 8A). A Kruskal-Wallis test was used to confirm the difference in ebullition according to sediments types $(n=37, p=0.029)$. The influence of water depth was also observed (Figure 8), with significantly higher ebullition during the low water season (Kruskal-Wallis, $\mathrm{n}=37, p=0.026$ ).

Whole basin $\mathrm{CH}_{4}$ emission from large rivers

The calculated surface area covered by rivers wider than $200 \mathrm{~m}$ in the Amazon basin was $91,212 \mathrm{~km}^{2}$. Flux rates were calculated separately for each tributary basin and then summed. Tapajos and Xingu Rivers presented significant difference in flux rates among seasons. Thus, an average for each season in each river was calculated and used for the river basin extrapolation. Additionally, for the Xingu basin extrapolation a seasonal average considering sites with mud was calculated separately from those with sand. This allowed a more precise extrapolation of the $\mathrm{CH}_{4}$ flux for large rivers in the whole Amazon basin, resulting in a mean flux of $0.49 \mathrm{Tg} \mathrm{CH}_{4} \mathrm{yr}^{-1}$, with a range calculated based on the standard error of the mean from 0.40 to $0.58 \mathrm{Tg} \mathrm{CH}_{4} \mathrm{yr}^{-1}$. 


\section{Discussion}

In the present study we found higher $\mathrm{CH}_{4}$ fluxes than previously reported. We believe that this is the result of our use of the multiple floating chambers approach for measuring $\mathrm{CH}_{4}$ emission from rivers and due to the inclusion of the major tributaries of the Amazon River, which increased the variability of river environments measured. The use of chambers and the several different rivers sampled enabled us to find hotspots where ebullition was very significant. Thus, capturing larger number of events with ebullitive fluxes could result in an even larger contribution of the Amazon in the $\mathrm{CH}_{4}$ global cycle than reported here.

\section{Comparison with previous estimates}

Previous studies in the Amazonian rivers, which only used dissolved measurements to calculate diffusive emission of $\mathrm{CH}_{4}$ (Bartlett et al., 1988, Richey et al., 1988), were significantly lower than our estimates using chambers and including ebullition. The previous Solimões/Amazon River channel $\mathrm{CH}_{4}$ flux ranged from 0.17 to $0.23 \mathrm{mmol} \mathrm{m} \mathrm{d}^{-1}$ (Bartlett et al., 1988, Richey et al., 1988). Including mean $\mathrm{CH}_{4}$ flux from the tributaries expanded the range for Amazonian river from 0.04 to $6.0 \mathrm{mmol} \mathrm{CH}_{4} \mathrm{~m}^{-2} \mathrm{~d}^{-1}$, found in the Madeira and Xingu Rivers, respectivley. Comparing only our sites within the same Solimões/Amazon River stretch we observed fluxes that were approximately twice as high as previous measurements. The use of floating chambers, when properly designed, is an efficient way to calculate $k$ and determine fluxes (Cole et al., 2010, Galfalk et al., 2013). Thus our result is more realistic than simulating fluxes from dissolved $\mathrm{CH}_{4}$ concentrations 
due to the effective calculation of $k$ and inclusion of ebullitive fluxes, which was overlooked previously in the relatively few studies that currently exist.

Spatiotemporal $\mathrm{CH}_{4}$ flux heterogeneity

Our results showed a trend of increasing fluxes downriver in Negro, Solimões, Madeira and Amazon Rivers. It is possible that the downstream flux increase could be influenced by a combination of factors such as $\mathrm{CH}_{4}$ concentration, and higher water turbulence caused by the confluence with another large river. This increasing trend in $\mathrm{CH}_{4}$ emissions downriver was also observed in the Yukon River and its tributaries (Striegl et al., 2012), but no further discussion regarding the causes was given.

Cross-channel profiles of dissolved $\mathrm{CH}_{4}$ in five locations of the Amazon River done by Richey et al. (1988) showed lower concentrations in the center compared to the banks. This is in agreement with patterns observed in lakes (Hofmann, 2013, Schilder et al., 2013). While our concentration results follow a similar trend to that of the Richey et al. (1988) data, the diffusive flux patterns we found are opposite in magnitude to the concentration trend with highest fluxes in the center of the channel (Figure 4a). Flux and concentration profiles in the Pará River followed the same pattern, increasing from the north to the south bank (Figure $4 b$ ). In both these rivers, there was a large tributary several kilometers upstream entering at the same channel side where our profiles showed higher dissolved $\mathrm{CH}_{4}$, indicating that the concentrations could be influenced by incomplete mixing and transport from tributaries upriver, as suggested by Bartlett et al. (1990). The local diffusive flux patterns result from a combination of concentration and water turbulence. The latter 
could be attributed to depth, water and wind speed in the river channel increasing the gas exchange coefficient.

Sites with mud sediments had higher total flux rates to the atmosphere than areas with mixtures of mud/sand or just sand. These mud sediment sites had flux rates even higher than observed in open water of lakes from the Amazon River floodplain (1.7 mmol $\mathrm{m}^{-2} \mathrm{~d}^{-1}$ ) (Bartlett et al., 1988, Crill et al., 1988) and similar to fluxes in reservoirs (0.9-5.2 mmol m${ }^{-2} \mathrm{~d}^{-1}$; Tucurui, Samuel and Balbina (Lima, 2005). These low water-speed areas which accumulate fine grained sediments rich in organic matter can function as local hotspots of $\mathrm{CH}_{4}$ production within the channel and could be used as a predictor of future $\mathrm{CH}_{4}$ hotspots in planned hydroelectric reservoirs in the Amazon basin.

Our results indicate higher total and diffusive fluxes in clear water rivers (Xingu and Tapajós) (Table 3 and Figure 5). M. F. F. L. Rasera (unpublished data) also found higher diffusive fluxes in clear water rivers (Araguaia, Javaés and Teles Pires) than in the Negro and Solimões Rivers, which represent respectively, black and white water river types. Despite the dominance of mud in our clear water sites, sand areas had similar fluxes, and both sediment types exhibited higher fluxes than those in black and white water sites. Clear water rivers are characterized by high level of dissolved oxygen and light penetration, both potentially inhibitory factors for methanotrophic bacteria activity (Dumestre et al., 1999, Rudd et al., 1976), which could indicate that in these rivers there is less methane oxidation in the water column. A further indicative of lower oxidation rates in studied clear water rivers is the more depleted isotopic signature ${ }^{13} \mathrm{C}_{-}-\mathrm{CH}_{4}$ in surface water than in black and white water rivers (H. O. Sawakuchi, unpublished data).

In regards to seasonal patterns in $\mathrm{CH}_{4}$ fluxes, our measurements showed significantly higher fluxes during the low water season. The same pattern was observed in 
tropical rivers in Africa (Kone et al., 2010) and temperate European rivers (Middelburg et $a l .$, 2002). These higher fluxes during low water season in Amazonian rivers indicate that adjacent flooded areas may not be as important sources of $\mathrm{CH}_{4}$ to the river channel as suspected previously (Bartlett et al., 1990, Devol et al., 1990, Richey et al., 1988). This pattern may be explained by the greater dilution of incoming $\mathrm{CH}_{4}$ from sediments and ground waters and greater time for $\mathrm{CH}_{4}$ oxidation in deeper water columns during high water periods. Both effects could contribute to the lower values observed during high water season. Furthermore, we registered most of the ebullition in depths between 10 and $20 \mathrm{~m}$ in areas where $\mathrm{CH}_{4}$ is produced within the channel. At these areas, the increase in hydrostatic pressure during high water season resulted in significantly lower ebullition. These changes in hydrostatic pressure and $\mathrm{CH}_{4}$ release through ebullition were also observed in a tidally influenced estuary in North Caroline (Martens \& Val Klump, 1984), and are common in lakes (Ostrovsky et al., 2008, Wik et al., 2013).

\section{Role of ebullition in Amazonian rivers}

Even though measurements were done mostly in the middle of the channel, ebullition was detected in all sorts of sediments, including areas with sand, and was an important pathway of $\mathrm{CH}_{4}$ emission. Thermogenic, geological sources of $\mathrm{CH}_{4}$ in ebullition cannot be excluded but seem unlikely. It is more likely that the ebullition in sites with sand on the bottom is driven by the degradation of buried layers below the sand with a higher content of organic matter. This was directly observed in a shallow area near the channel margin of the Xingu River, where a bank of leaves was buried below about $25 \mathrm{~cm}$ of coarse sand and a large amount of bubbles was being released. Ebullitive fluxes in stream and 
rivers can be responsible for $10 \%$ to $80 \%$ of the $\mathrm{CH}_{4}$ transport and seem positively related with the proportion of clay and silt in the bed sediment (Baulch et al., 2011).

\section{$\mathrm{CH}_{4}$ flux from Amazonian rivers in the global scenario}

We estimate an emission of $\mathrm{CH}_{4}$ from large rivers in the Amazon Basin of $0.49 \mathrm{Tg}$

$\mathrm{CH}_{4} \mathrm{yr}^{-1}$ (standard error $\pm 0.09 \mathrm{Tg} \mathrm{CH}_{4} \mathrm{yr}^{-1}$ ). This mean value represents approximately 1.7 $\%$ of the estimated emissions from wetlands in Amazon (Melack et al., 2004). Our estimate accounting for large rivers only in the Amazon basin, corresponds to $12.5 \%$ of this amount. Compared to the $\mathrm{CH}_{4}$ fluxes from rivers estimated by Bastviken et al. (2011), the Amazonian rivers contribute with 44 - $65 \%$ of the global tropical river emissions, and 22$28 \%$ of the global river emission. Using the same tropical and global river areas as in Bastviken et al. (2011), 176,856 $\mathrm{km}^{2}$ and $357,627 \mathrm{~km}^{2}$, respectively, and our average value of $\mathrm{CH}_{4}$ flux from Amazonian rivers, we compute a new tropical river emission estimate ranging from $1.18-1.66 \mathrm{Tg} \mathrm{CH}_{4} \mathrm{yr}^{-1}$ which is to $31-84 \%$ higher than the previous estimate done by Bastviken et al. (2011) using temperate rivers as reference. Our global estimate ranges from 1.78 to $2.26 \mathrm{Tg} \mathrm{CH}_{4} \mathrm{yr}^{-1}$ which is $19-51 \%$ higher than the previous 1.5 $\mathrm{Tg} \mathrm{CH}_{4} \mathrm{yr}^{-1}$ estimated by Bastviken et al. (2011).

Our study shows a high heterogeneity in $\mathrm{CH}_{4}$ flux across spatial and temporal scales from large rivers in the Amazon Basin. At the river scale, local characteristics, such as $\mathrm{CH}_{4}$ concentration and water turbulence, could lead to different fluxes rates along the river and across the channel. Furthermore, geomorphologic features can drive different patterns of sediment deposition within river channels, creating hotspots of $\mathrm{CH}_{4}$ production with high ebullitive fluxes. At the basin scale, geologic formations of the basin terrain will have an 
important influence on the water type, which in turn, can influence emission through oxidation. Despite the spatial difference within rivers, there is still a clear seasonal signal in $\mathrm{CH} 4$ emissions. Therefore, all this variability in $\mathrm{CH}_{4}$ fluxes from rivers should be addressed and considered for extrapolations.

The $\mathrm{CH}_{4}$ emission rates estimated here put the large Amazonian rivers in the context of global $\mathrm{CH}_{4}$ sources. As we observed, tropical rivers have higher emission than temperate rivers. However, specific and more detailed studies in small rivers and streams in the Amazon Basin and in other tropical rivers were not included in this study and are still needed. More importantly, we have shown that future flux measurements in rivers should be designed to use multiple floating chambers to cover not only diffusive flux but also ebullition. More studies are needed to better understand the high variability of fluxes of $\mathrm{CH}_{4}$ within rivers and more accurate $\mathrm{CH}_{4}$ budgets, including sources and sinks, are still needed to better constrain global river emissions of $\mathrm{CH}_{4}$. 


\section{Acknowledgments}

This study was supported by FAPESP, Grants 08/58089-9, 2011/06609-1, 2011/14502-2 and 2012/17359-9, for financial support and scholarship. We thank

Alexandra Montebello and Maria de Fátima F. L. Rasera for assistance in the laboratory;

Hillândia B. da Cunha, Ingo Wahnfried, José Mauro S. Moura, Carlos Henrique Grohmann, Tatiana S. Pereira, Daímio C. Brito, Alan C. Cunha and all people assisted in field work and Will Gagne-Maynard and two anonymous reviewers for their constructive comments to the manuscript. 


\section{References}

Abril G, Guerin F, Richard S et al. (2005) Carbon dioxide and methane emissions and the carbon budget of a 10-year old tropical reservoir (Petit Saut, French Guiana). Global Biogeochemical Cycles, 19.

Archer Aw (2005) Review of Amazonian Depositional Systems. In: Fluvial Sedimentology VII. (ed Blum M Ms, Leclair S) pp Page., Blackwell Publishing Ltd.

Bartlett Kb, Crill Pm, Bonassi Ja, Richey Je, Harriss Rc (1990) Methane flux from the Amazon River floodplain - emission during rising water. Journal of Geophysical Research-Atmospheres, 95, 16773-16788.

Bartlett Kb, Crill Pm, Sebacher Di, Harriss Rc, Wilson Jo, Melack Jm (1988) Methane flux from the central amazonian floodplain. Journal of Geophysical ResearchAtmospheres, 93, 1571-1582.

Bastviken D, Cole J, Pace M, Tranvik L (2004) Methane emissions from lakes:

Dependence of lake characteristics, two regional assessments, and a global estimate. Global Biogeochemical Cycles, 18, Gb4009.

Bastviken D, Santoro Al, Marotta H, Pinho Lq, Calheiros Df, Crill P, Enrich-Prast A (2010) Methane Emissions from Pantanal, South America, during the Low Water Season: Toward More Comprehensive Sampling. Environmental Science \& Technology, 44, 5450-5455.

Bastviken D, Tranvik Lj, Downing Ja, Crill Pm, Enrich-Prast A (2011) Freshwater Methane Emissions Offset the Continental Carbon Sink. Science, 331. 
Battin Tj, Luyssaert S, Kaplan La, Aufdenkampe Ak, Richter A, Tranvik Lj (2009) The boundless carbon cycle. Nature Geoscience, 2, 598-600.

Baulch Hm, Dillon Pj, Maranger R, Schiff Sl (2011) Diffusive and ebullitive transport of methane and nitrous oxide from streams: Are bubble-mediated fluxes important? Journal of Geophysical Research-Biogeosciences, 116, G04028.

Belger L, Forsberg Br, Melack Jm (2011) Carbon dioxide and methane emissions from interfluvial wetlands in the upper Negro River basin, Brazil. Biogeochemistry, 105, 171-183.

Brown J, Loveland T, Ohlen D, Zhu Z (2003) LBA Regional Land Cover from AVHRR, 1km, Version 1.2 (IGBP). Available on-line [http://daac.ornl.gov] from Oak Ridge National Laboratory Distributed Active Archive Center, Oak Ridge, Tennessee, U.S.A. doi:10.3334/ORNLDAAC/679.

Cole Jj, Bade Dl, Bastviken D, Pace Ml, Van De Bogert M (2010) Multiple approaches to estimating air-water gas exchange in small lakes. Limnology and OceanographyMethods, 8, 285-293.

Cole Jj, Caraco Nf (1998) Atmospheric exchange of carbon dioxide in a low-wind oligotrophic lake measured by the addition of SF6. Limnology and Oceanography, 43, 647-656.

Cole Jj, Prairie Yt, Caraco Nf et al. (2007) Plumbing the global carbon cycle: Integrating inland waters into the terrestrial carbon budget. Ecosystems, 10, 171-184.

Crill Pm, Bartlett Kb, Wilson Jo et al. (1988) Tropospheric methane from an amazonian floodplain lake. Journal of Geophysical Research-Atmospheres, 93, 1564-1570. 
Devol Ah, Richey Je, Clark Wa, King Sl, Martinelli La (1988) Methane emissions to the troposphere from the Amazon floodplain. Journal of Geophysical ResearchAtmospheres, 93, 1583-1592.

Devol Ah, Richey Je, Forsberg Br, Martinelli La (1990) Seasonal dynamics in methane emission from the amazon River floodplain to the troposphere. Journal of Geophysical Research-Atmospheres, 95, 16417-16426.

Dumestre Jf, Guezennec J, Galy-Lacaux C, Delmas R, Richard S, Labroue L (1999) Influence of light intensity on methanotrophic bacterial activity in Petit Saut Reservoir, French Guiana. Applied and Environmental Microbiology, 65, 534-539.

Galfalk M, Bastviken D, Fredriksson S, Arneborg L (2013) Determination of the piston velocity for water-air interfaces using flux chambers, acoustic Doppler velocimetry, and IR imaging of the water surface. Journal of Geophysical ResearchBiogeosciences, 118, 770-782.

Grimm Am, Vera Cs, Mechoso Cr (2005) The South American Monsoon System. The Global Monsoon System: Research and Forecast, 219-238.

Hofmann H (2013) Spatiotemporal distribution patterns of dissolved methane in lakes: How accurate are the current estimations of the diffusive flux path? Geophysical Research Letters, 40, 2779-2784.

Jahne B, Munnich Ko, Bosinger R, Dutzi A, Huber W, Libner P (1987) On the parameters influencing air-water gas exchange. Journal of Geophysical Research-Oceans, 92, 1937-1949.

Kemenes A, Forsberg Br, Melack Jm (2007) Methane release below a tropical hydroelectric dam. Geophysical Research Letters, 34. 
Kone Yjm, Abril G, Delille B, Borges Av (2010) Seasonal variability of methane in the rivers and lagoons of Ivory Coast (West Africa). Biogeochemistry, 100, 21-37.

Latrubesse Em, Stevaux Jc, Sinha R (2005) Tropical rivers. Geomorphology, 70, 187-206.

Lima Ibt (2005) Biogeochemical distinction of methane releases from two Amazon hydroreservoirs. Chemosphere, 59, 1697-1702.

Martens Cs, Val Klump J (1984) Biogeochemical cycling in an organic-rich coastal marine basin 4. An organic carbon budget for sediments dominated by sulfate reduction and methanogenesis. Geochimica et Cosmochimica Acta, 48, 1987-2004.

Mayorga E, Aufdenkampe Ak (2002) Processing of bioactive elements in the amazon river system. In: The ecohydrology of south american rivers and wetlands. (ed Mcclain Me) pp Page. Oxfordshire, IAHS Press.

Melack Jm, Hess Ll, Gastil M, Forsberg Br, Hamilton Sk, Lima Ibt, Novo E (2004) Regionalization of methane emissions in the Amazon Basin with microwave remote sensing. Global Change Biology, 10, 530-544.

Middelburg Jj, Nieuwenhuize J, Iversen N et al. (2002) Methane distribution in European tidal estuaries. Biogeochemistry, 59, 95-119.

Ostrovsky I, Mcginnis Df, Lapidus L, Eckert W (2008) Quantifying gas ebullition with echosounder: the role of methane transport by bubbles in a medium-sized lake. Limnology and Oceanography-Methods, 6, 105-118.

Raymond Pa, Hartmann J, Lauerwald R et al. (2013) Global carbon dioxide emissions from inland waters. Nature, 503, 355-359.

Richey Je, Devol Ah, Wofsy Sc, Victoria R, Riberio Mng (1988) Biogenic gases and the oxidation and reduction of carbon in Amazon river and floodplain waters. Limnology and Oceanography, 33, 551-561. 
Richey Je, Melack Jm, Aufdenkampe Ak, Ballester Vm, Hess Ll (2002) Outgassing from Amazonian rivers and wetlands as a large tropical source of atmospheric CO2. Nature, 416, 617-620.

Rosenqvist A, Forsberg Br, Pimentel T, Rauste Ya, Richey Je (2002) The use of spaceborne radar data to model inundation patterns and trace gas emissions in the central Amazon floodplain. International Journal of Remote Sensing, 23, 13031328.

Rudd Jwm, Furutani A, Flett Rj, Hamilton Rd (1976) Factors controlling methane oxidation in Shield Lakes: The role of nitrogen fixation and oxygen concentration. Limnology and Oceanography, 21, 357-364.

Schilder J, Bastviken D, Van Hardenbroek M, Kankaala P, Rinta P, Stoetter T, Heiri O (2013) Spatial heterogeneity and lake morphology affect diffusive greenhouse gas emission estimates of lakes. Geophysical Research Letters, 40, 5752-5756.

Sioli H (1985) Amazônia: Fundamentos de ecologia da maior região de florestas tropicais, Petrópolis, Editora Vozes.

Striegl Rg, Dornblaser Mm, Mcdonald Cp, Rover Jr, Stets Eg (2012) Carbon dioxide and methane emissions from the Yukon River system. Global Biogeochemical Cycles, 26, GB0E05.

Tranvik Lj, Downing Ja, Cotner Jb et al. (2009) Lakes and reservoirs as regulators of carbon cycling and climate. Limnology and Oceanography, 54, 2298-2314.

Vera C, Higgins W, Amador J et al. (2006) Toward a unified view of the American Monsoon Systems. Journal of Climate, 19, 4977-5000.

Wanninkhof R (1992) Relationship betwenn wind-speed and gas-exchange over the ocean. Journal of Geophysical Research-Oceans, 97, 7373-7382. 
Wiesenburg Da, Guinasso N1 (1979) Equilibrium solubilities of methane, carbonmonoxide, and hydrogen in water and sea-water. Journal of Chemical and Engineering Data, 24, 356-360.

Wik M, Crill Pm, Varner Rk, Bastviken D (2013) Multiyear measurements of ebullitive methane flux from three subarctic lakes. Journal of Geophysical Research: Biogeosciences, 118, 1307-1321. 
Table 1. Additional information about sampling sites showed in Figure 1.

\begin{tabular}{|c|c|c|c|c|c|c|c|}
\hline \multirow{2}{*}{$\begin{array}{c}\text { Location } \\
\text { no }^{\mathbf{a}}\end{array}$} & \multirow{2}{*}{ River } & \multirow{2}{*}{ Sediment } & \multirow{2}{*}{ Water type } & \multirow{2}{*}{ Sedimentary dynamics } & \multicolumn{3}{|c|}{ Water seasons ${ }^{b}$} \\
\hline & & & & & Low & High & Falling \\
\hline 1 & Negro & Sand/Mud & Black & Lake-like & $\mathrm{x}$ & $\mathrm{x}$ & - \\
\hline 2 & Negro & Sand & Black & Lake-like & $\mathrm{x}$ & $\mathrm{x}$ & - \\
\hline 3 & Negro & Sand/Mud & Black & Lake-like & $\mathrm{x}$ & $\mathrm{x}$ & - \\
\hline 4 & Solimões & Sand & White & Straight fluvial channel & $\mathrm{x}$ & $\mathrm{x}$ & - \\
\hline 5 & Solimões & Sand & White & Straight fluvial channel & $\mathrm{x}$ & $\mathrm{x}$ & - \\
\hline 6 & Solimões & Sand & White & Straight fluvial channel & $\mathrm{x}$ & $\mathrm{x}$ & - \\
\hline 7 & Preto da Eva & Mud & Black & Lake-like & - & $\mathrm{x}$ & - \\
\hline 8 & Madeira & Sand & White & Straight fluvial channel & - & $\mathrm{x}$ & - \\
\hline 9 & Madeira & Sand & White & Straight fluvial channel & - & $\mathrm{x}$ & - \\
\hline 10 & Madeira & Sand & White & Straight fluvial channel & - & $\mathrm{x}$ & - \\
\hline 11 & Lake Curuai & Mud & White & Floodplain lake & - & - & $\mathrm{x}$ \\
\hline 12 & Tapajós & Mud & Clear & Straight channel & $\mathrm{x}$ & - & - \\
\hline 13 & Tapajós & Mud & Clear & Lake-like & $\mathrm{x}$ & $\mathrm{x}$ & - \\
\hline 14 & Tapajós & Mud & Clear & Lake-like & $\mathrm{x}$ & $\mathrm{x}$ & $\mathrm{x}$ \\
\hline 15 & Tapajós & Mud & Clear & Lake-like & $\mathrm{x}$ & $\mathrm{x}$ & - \\
\hline 16 & Xingu & Sand & Clear & Rapids-waterfalls & $\mathrm{x}$ & $\mathrm{x}$ & - \\
\hline 17 & Xingu & Sand & Clear & Rapids-waterfalls & $\mathrm{x}$ & $\mathrm{x}$ & - \\
\hline 18 & Xingu & Sand & Clear & Lake-like & $\mathrm{x}$ & $\mathrm{x}$ & - \\
\hline 19 & Xingu & Mud & Clear & Lake-like & $\mathrm{x}$ & $\mathrm{x}$ & - \\
\hline 20 & Xingu & Mud & Clear & Lake-like & $\mathrm{x}$ & $\mathrm{x}$ & - \\
\hline 21 & Xingu & Mud & Clear & Lake-like & $\mathrm{x}$ & - & - \\
\hline 22 & Xingu & Mud & Clear & Lake-like & $\mathrm{x}$ & $\mathrm{x}$ & - \\
\hline 23 & Pará & - & White & Estuarine channel & - & - & $\mathrm{x}$ \\
\hline 24 & Pará & - & White & Estuarine channel & - & - & $\mathrm{x}$ \\
\hline 25 & Pará & - & White & Estuarine channel & - & - & $\mathrm{x}$ \\
\hline 26 & Amazon & Sand/Mud & White & Straight fluvial channel & - & $\mathrm{x}$ & - \\
\hline 27 & Amazon & - & White & Straight fluvial channel & - & $\mathrm{x}$ & $\mathrm{x}$ \\
\hline 28 & Amazon & - & White & Straight fluvial channel & - & - & $\mathrm{x}$ \\
\hline 29 & Amazon & - & White & Straight fluvial channel & - & - & $\mathrm{x}$ \\
\hline 30 & Amazon & Sand & White & Straight fluvial channel & $\mathrm{x}$ & - & - \\
\hline 31 & Amazon & Sand & White & Straight fluvial channel & $\mathrm{x}$ & $\mathrm{x}$ & - \\
\hline 32 & Amazon & Sand/Mud & White & Straight fluvial channel & - & $\mathrm{x}$ & - \\
\hline 33 & Amazon & - & White & Estuarine channel & - & - & $\mathrm{x}$ \\
\hline 34 & Amazon & - & White & Estuarine channel & - & - & $\mathrm{x}$ \\
\hline
\end{tabular}

${ }^{\mathrm{a}}$ Location numbers refer to numbers of sampling locations in Figure 1.

${ }^{\mathrm{b}}$ Seasons when site was measured. 


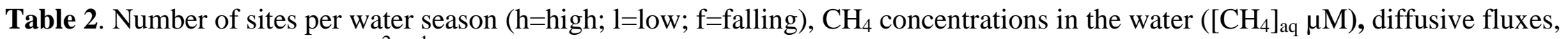
ebullition, total fluxes $\left(\mathrm{mmol} \mathrm{m} \mathrm{m}^{-2}\right)$ and percentage of ebullition for rivers.

\begin{tabular}{|c|c|c|c|c|c|c|c|c|c|}
\hline & \multicolumn{9}{|c|}{ Rivers } \\
\hline & Negro & Solimões & Preto & Madeira & $\begin{array}{c}\text { Lake } \\
\text { Curuai }\end{array}$ & Tapajós & Xingu & Amazon & Pará \\
\hline $\begin{array}{l}n \text { Site/Season } \\
{[\mathrm{CH} 4]_{\mathrm{aq}}}\end{array}$ & $31,3 \mathrm{~h}$ & $31,3 \mathrm{~h}$ & $1 \mathrm{~h}$ & $3 \mathrm{~h}$ & 1f & $41,3 \mathrm{~h}, 1 \mathrm{f}$ & $71,6 \mathrm{~h}$ & $2 \mathrm{l}, 4 \mathrm{~h}, 5 \mathrm{f}$ & $3 f$ \\
\hline Mean $( \pm \mathrm{SD})$ & $0.07 \pm 0.03$ & $0.04 \pm 0.04$ & 0.06 & $0.03 \pm 0.01$ & 0.17 & $0.16 \pm 0.20$ & $0.23 \pm 0.10$ & $0.09 \pm 0.08$ & $0.05 \pm 0.01$ \\
\hline Median & 0.08 & 0.03 & 0.06 & 0.03 & 0.17 & 0.05 & 0.24 & 0.08 & 0.06 \\
\hline Range & $0.02-0.10$ & $0.02-0.12$ & - & 0.03-0.04 & - & $0.04-0.50$ & $0.03-0.41$ & $0.02-0.31$ & 0.04-0.06 \\
\hline$n$ & 6 & 6 & 1 & 3 & 1 & 8 & 13 & 11 & 3 \\
\hline \multicolumn{10}{|l|}{ Diffusive flux } \\
\hline Mean $( \pm \mathrm{SD})$ & $0.48 \pm 0.42$ & $0.25 \pm 0.16$ & $0.09 \pm 0.01$ & $0.04 \pm 0.04$ & $1.13 \pm 0.27$ & $2.27 \pm 3.74$ & $2.95 \pm 3.87$ & $1.06 \pm 1.46$ & $0.25 \pm 0.06$ \\
\hline Median & 0.32 & 0.26 & 0.09 & 0.02 & 1.07 & 0.55 & 1.35 & 0.37 & 0.25 \\
\hline Range & $0.05-1.25$ & $0.04-0.58$ & $0.07-0.11$ & $0.01-0.18$ & $0.85-1.59$ & $0.16-14.75$ & $0.13-18.57$ & $0.10-6.60$ & $0.13-0.34$ \\
\hline$n$ & 58 & 52 & 15 & 40 & 10 & 65 & 100 & 92 & 20 \\
\hline \multicolumn{10}{|l|}{ Total flux } \\
\hline Mean $( \pm$ SD $)$ & $0.54 \pm 0.56$ & $0.31 \pm 0.35$ & $0.09 \pm 0.01$ & $0.04 \pm 0.04$ & $1.13 \pm 0.27$ & $2.41 \pm 4.10$ & $5.96 \pm 9.15$ & $1.35 \pm 2.15$ & $0.31 \pm 0.31$ \\
\hline Median & 0.33 & 0.26 & 0.09 & 0.02 & 1.07 & 0.55 & 1.78 & 0.38 & 0.25 \\
\hline Range & $0.05-3.36$ & $0.04-2.54$ & $0.07-0.11$ & $0.01-0.18$ & $0.85-1.59$ & $0.16-16.14$ & $0.13-40.26$ & $0.10-10.03$ & $0.13-1.62$ \\
\hline$n$ & 58 & 52 & 15 & 40 & 10 & 65 & 100 & 92 & 20 \\
\hline \multicolumn{10}{|l|}{ Ebullition } \\
\hline Mean $( \pm \mathrm{SD})^{1}$ & $0.06 \pm 0.34$ & $0.05 \pm 0.34$ & 0 & 0 & 0 & $0.14 \pm 0.88$ & $3.01 \pm 7.14$ & $0.29 \pm 1.32$ & $0.07 \pm 0.30$ \\
\hline Range $^{2}$ & $0.18-2.58$ & $0.24-2.48$ & - & - & - & $2.28-6.73$ & $1.34-35.66$ & $3.11-9.34$ & 1.33 \\
\hline$n$ chambers $^{3}$ & 4 & 2 & 0 & 0 & 0 & 2 & 23 & 5 & 1 \\
\hline$n$ occurence 4 & 4 & 2 & 0 & 0 & 0 & 1 & 8 & 3 & 1 \\
\hline Ebullition (\%) & 11 & 17 & 0 & 0 & 0 & 6 & 51 & 22 & 21 \\
\hline
\end{tabular}

${ }^{\top}$ Total contribution of ebullition per river. The mean ebullition was calculated normalizing the area covered by all chambers used per site in the river, including those not receiving ebullition.

${ }^{2}$ Minimum and maximum ebullition captured in a single chamber per river

${ }^{3}$ Number of chambers receiving ebullition.

${ }^{4}$ Number of measurements where ebullition was found in at least one of the chambers. 
Table 3. Total $\mathrm{CH}_{4}$ flux versus sediment type, water type and season.

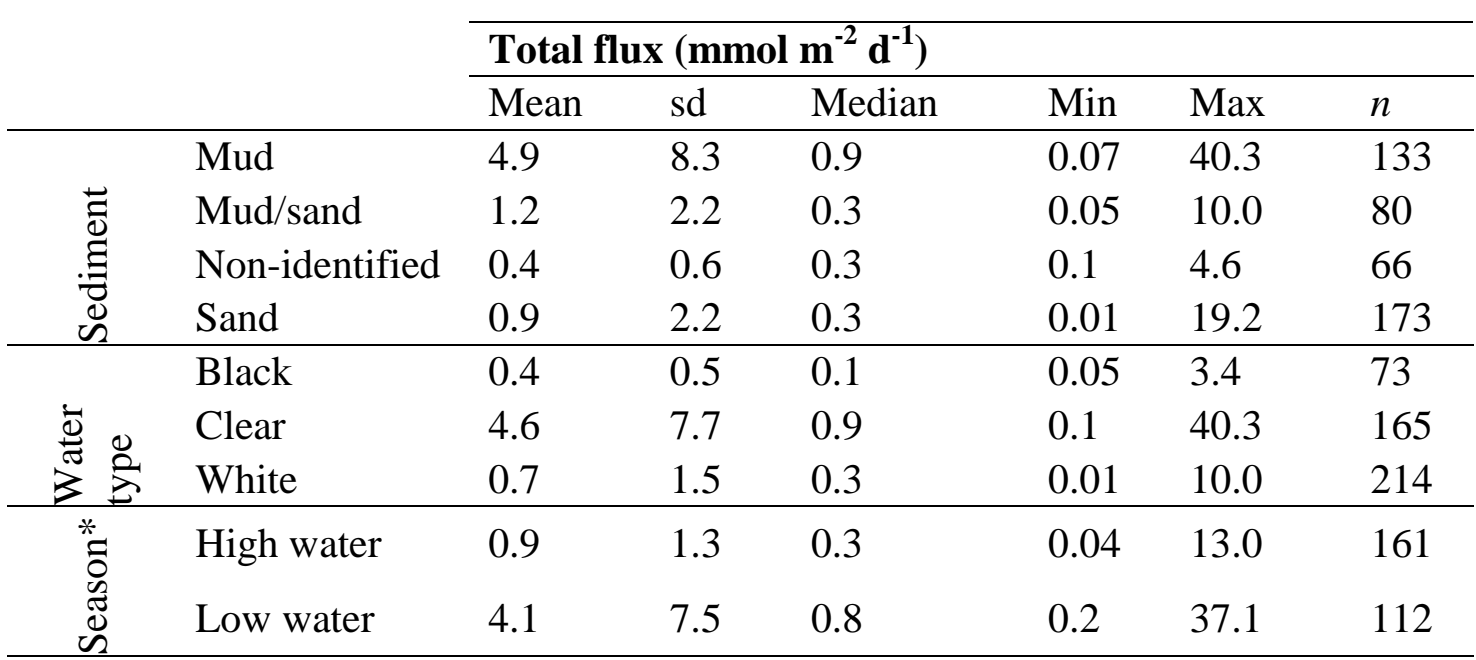

*Here we considered only sites sampled in both seasons $(n=16)$.

sd: standard deviation

$\mathrm{n}$ : number of measurements 


\section{Figure legends}

Figure 1. Sites of flux measurements performed in different seasons and tributaries of the Amazon River system. The numbers in parentheses in the legend indicate how many sites were measured in each season. See Tables 1 and 2 for more site information.

Figure 2. Frequency distribution of the Calculated $k_{600} /$ Minimum $k_{600}$ ratio for the specific site and measurement period using floating chamber measurements, used for distinction between fluxes consisting of both ebullition and diffusion and those only of diffusiion. See text for details.

Figure 3. Diffusive fluxes (log transformed) between sites measured in each river. Numbers in the $\mathrm{x}$ axis are the sites showed in Figure 1 and Table 1. Letters above or below the boxes indicate the grouping of sites within each river based on a one-way ANOVA with Tukey's test $(\mathrm{p}<0.05)$ to determine which sites had similar emissions (e.g. Sites with an $a$ in their letter combination were significantly different from those without an $a$ in their combination).

Figure 4. Mean and standard deviation of diffusive flux and concentration of $\mathrm{CH}_{4}$ in the cross-section profiles of the (a) Amazon and (b) Pará Rivers.

Figure 5. $\log _{10}$ of total $\mathrm{CH}_{4}$ flux (mmol m $\mathrm{m}^{-2} \mathrm{~d}^{-1}$ ) comparisons of sites in regards to (a) different types of sediments, (b) source river, (c) river water type, and (d) river water level (seasonal comparison performed with only sites measured during both seasons). Letters above graphics show grouping according to Tukey post-hoc test $(\mathrm{p}<0.05)$. Figure 6. Seasonal total flux comparison per river considering only sites measured during both high $(\mathrm{H})$ and low $(\mathrm{L})$ water seasons.

Figure 7. Average $\mathrm{CH}_{4}$ fluxes via diffusion and ebullition for each river. Error bars show the standard deviation. 
Figure 8. (a) Ebullition according to depth and sediment type for each site it was observed; (b) Seasonal influence on ebullition. Individual chambers receiving ebullition was considered here. 
Figure 1

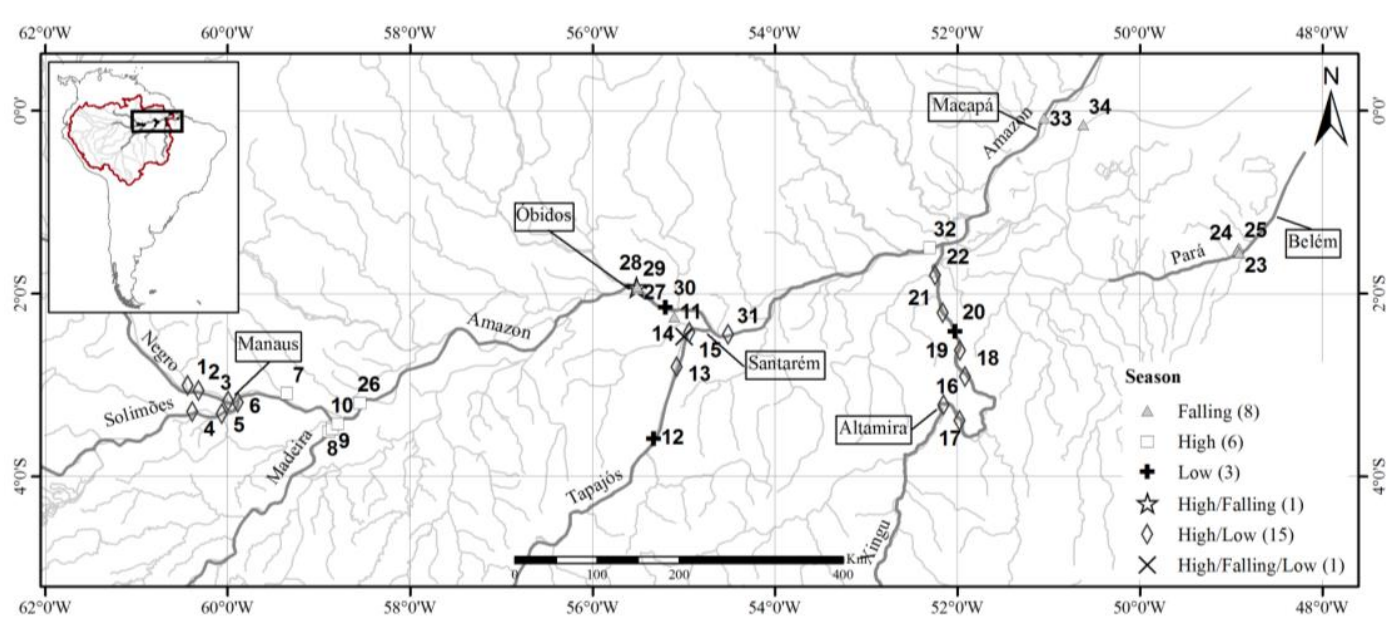


Figure 2

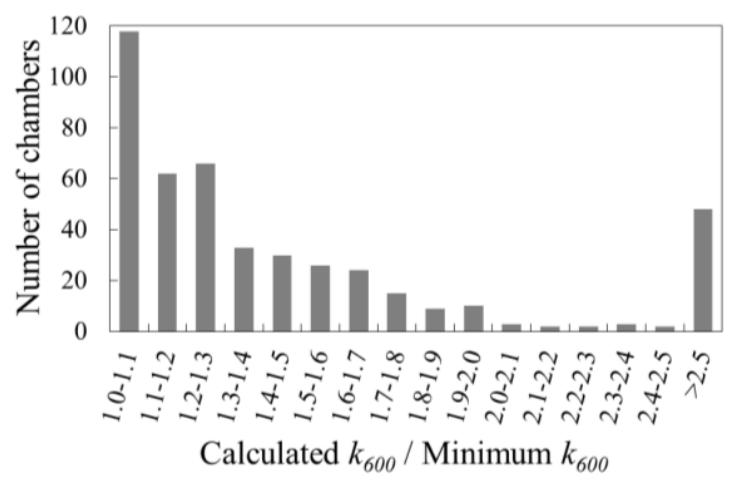


Figure 3

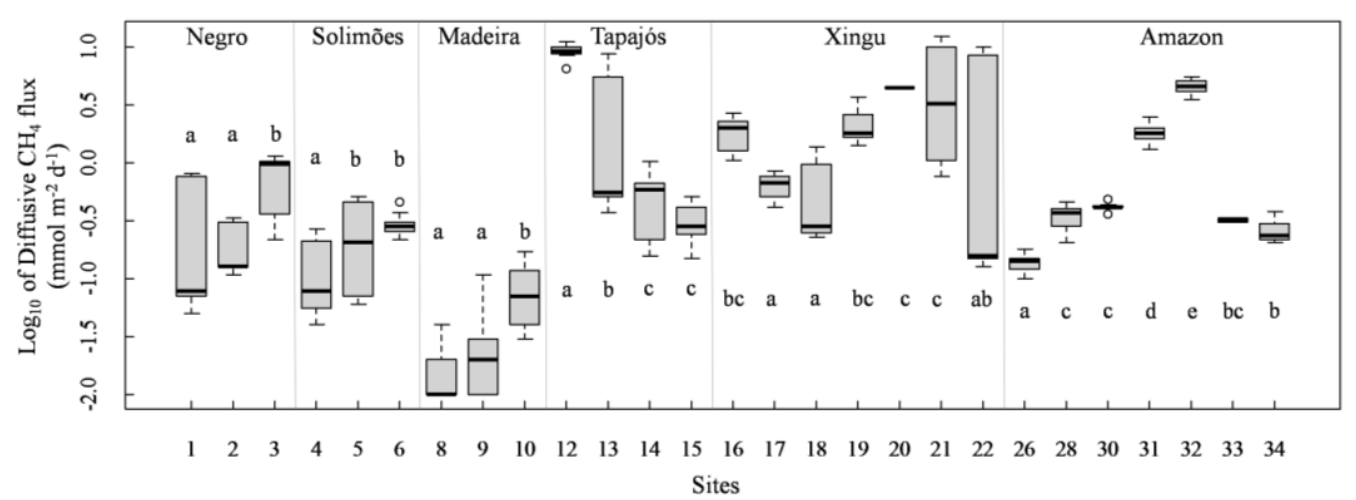


Figure 4
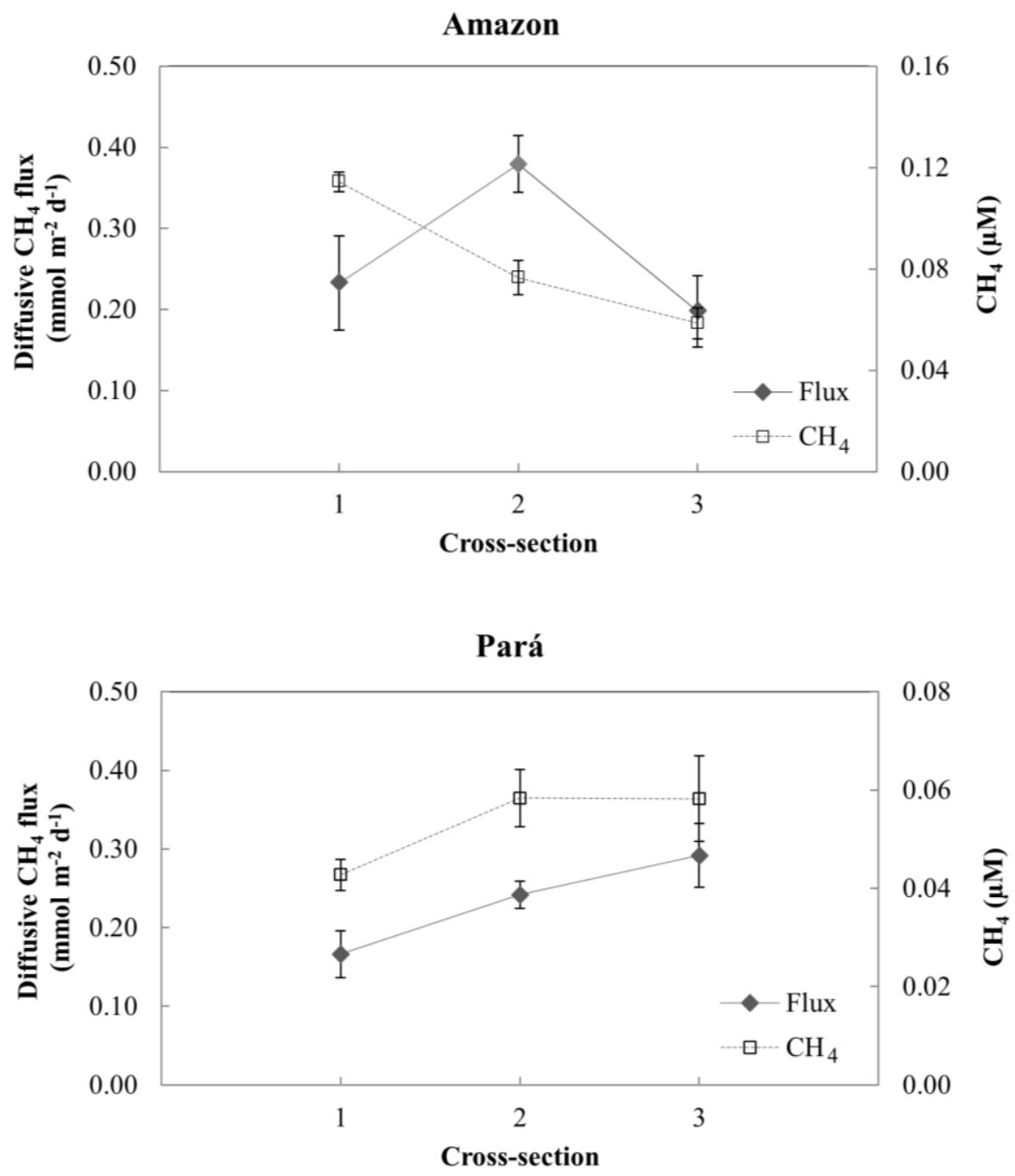
Figure 5
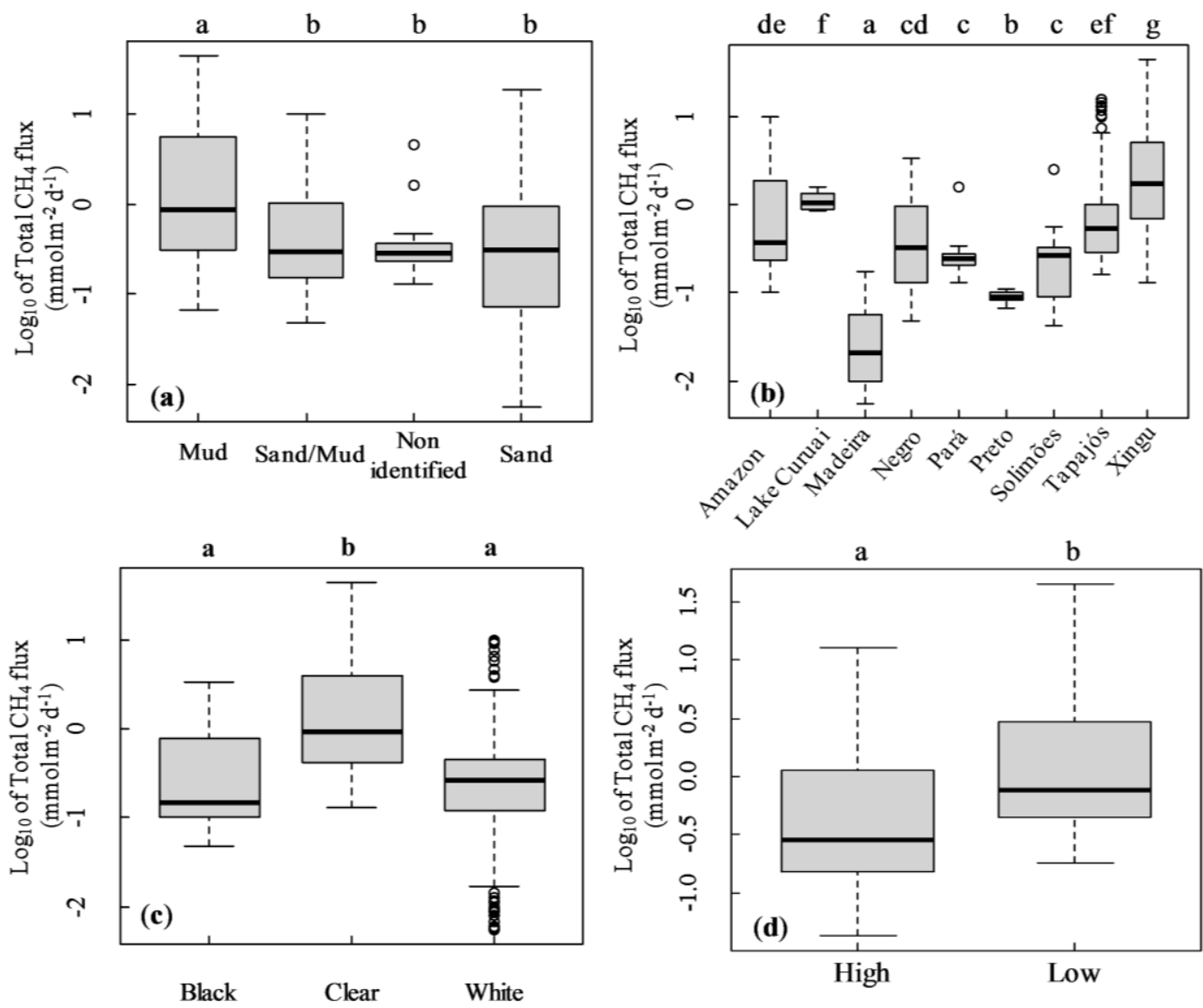
Figure 6

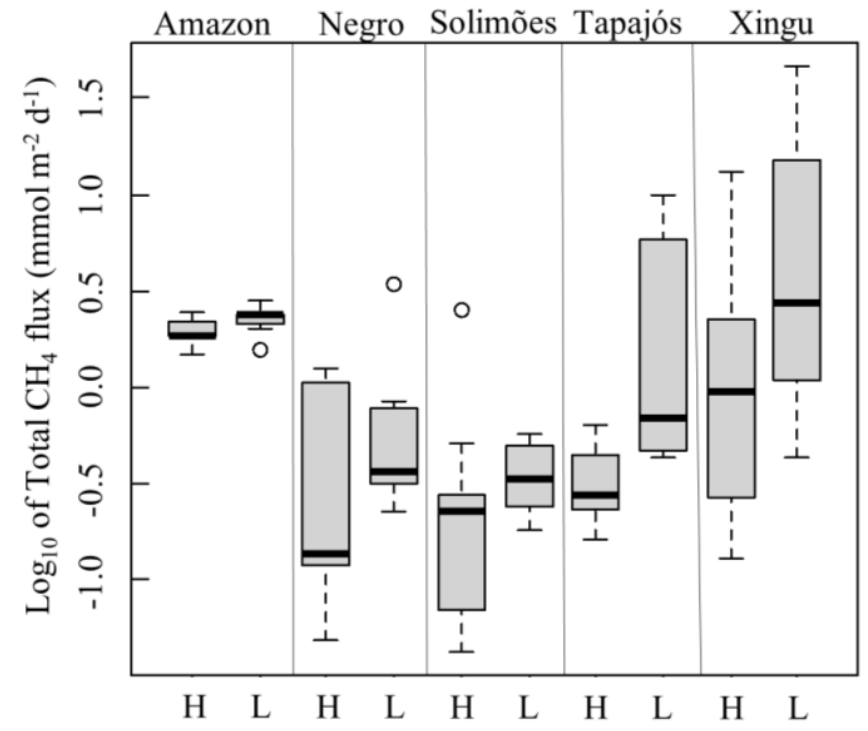


Figure 7

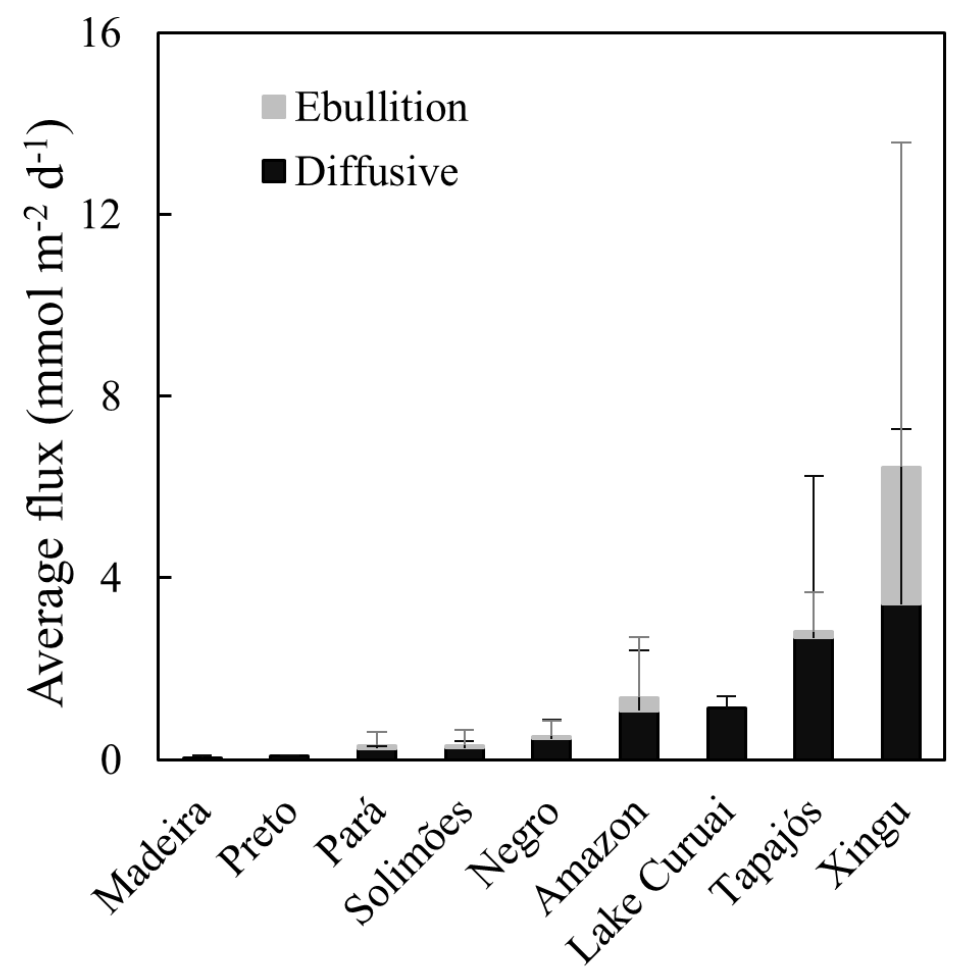


Figure 8
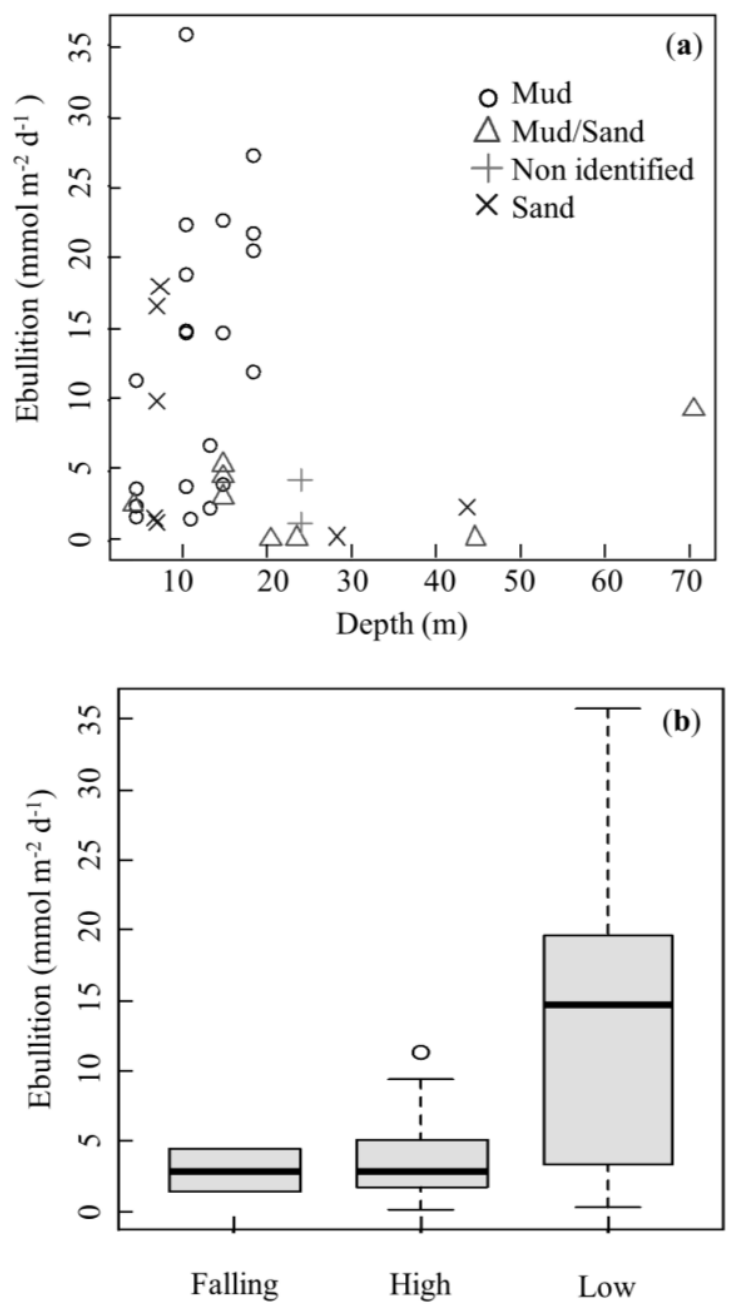